ACTA MYCOLOGICA

Vol. 44 (2): 201-210

2009
Dedicated to Professor Krystyna Czyżewska

in honour of 40 years of her scientific activity

\title{
Some new records of Rhizocarpon from North-Eastern Poland and North-Western Belarus
}

\author{
VLADIMIR V. GOLUBKOV ${ }^{1}$ and ANNA MATWIEJUK ${ }^{2}$ \\ ${ }^{1}$ Department of Botany, Faculty of Biology and Ecology, Ya. Kupala Hrodna State University \\ Azheshka Str. 22, BY-230023 Hrodna, Belarus, vgolubkov@grsu.by, vgolubkov@tut.by \\ ${ }^{2}$ Department of Botany, Institute of Biology, University of Bialystok \\ Świerkowa 20B, PL-15-950 Białystok, matwiej@uwb.edu.pl
}

Golubkov V. V., Matwiejuk A.: Some new records of Rhizocarpon from North-Eastern Poland and North-Western Belarus. Acta Mycol. 44 (2): 201-210, 2009.

New localities of Rhizocarpon distinctum, $R$. geographicum and $R$. reductum are reported from NE Poland. Rhizocarpon distinctum, $R$. grande, $R$. hochstetteri, $R$. lavatum, $R$. petraeum, $R$. polycarpum and $R$. reductum are reported from NW Belarus for the first time. Rhizocarpon hochstetteri, $R$. lavatum and $R$. polycarpum are new to Belarus. A key to species occurring in the area is given.

Key words: lichenized fungi, Rhizocarpon, new localities, Poland, Belarus

\section{INTRODUCTION}

Rhizocarpon Ramond ex DC. is a large genus of ca 200 species belonging to the family Rhizocarpaceae. It is widely distributed throughout the world, especially in alpine and polar regions. Species of the genus grow on rock and are long living. They have been widely used in studies on moraine dating in a procedure known as lichenometry.

The species of Rhizocarpon predominantly colonise siliceous rocks, although some species occur on basic substrates; a number of taxa are parasitic on other lichens (Poelt, Hafellner 1982; Poelt, Vězda 1984; Holtan-Hartwig, Timdal 1987; Poelt 1990).

Thomson (1967) divided the genus Rhizocarpon into taxa with a yellow thallus containing rhizocarpic acid (subgenus Rhizocarpon) and taxa with white, ashy or brown thalli lacking rhizocarpic acid (subgenus Phaeothallus). A comprehensive taxonomic study of yellow species of Rhizocarpon in Europe was conducted by Runemark (1956a, b), but intra-specific variation of the $R$. geographicum complex is still 
unclear (Wirth 1995). A comprehensive revision of the so-called R. obscuratum complex with taxa containing hyaline and muriform ascospores was carried by Fryday (2000a) and of the so-called $R$. hochstetteri complex with taxa containing hyline and one-septate ascospores was carried out by Fryday (2002). In the Nordic countries, the taxonomy of the non-yellow species of Rhizocarpon with hyaline and muriform ascospores is recognized by Ihlen (2004).

The knowledge of the species diversity of Rhizocarpon in north-eastern Poland is relatively good as reflected in literature data (e.g., Zielińska 1980; Fałtynowicz 1994; Bystrek, Kolanko 2000; Kukwa, Fałtynowicz 2002; Cieśliński 2003; Sparrius 2003; Zalewska et al. 2004a, b; Kolanko 2005; Kubiak 2005; Matwiejuk 2008), while it is insufficient in Belarus. Data mostly from Central and Eastern Belarus have been reported (Gorbach 1973; Golubkov 1987). Cieśliński (2003) reports six species from NE Poland, $R$. distinctum, $R$. eupetraeum, $R$. geographicum, $R$. lecanorinum, $R$. obscuratum and $R$. polycarpum. Zalewska et al. (2004b) confirmed the occurrence of five of the above species (except $R$. eupetraeum) and reported $R$. reductum from the Suwalski Landscape Park, where the greatest concentrations of boulders in NE Poland can be found. Gorbach (1973) lists six species for Belarus: R. geographicum, $R$. grande, $R$. distinctum, $R$. concentricum, $R$. obscuratum and $R$. reductum.

\section{STUDY AREA}

The study area comprises north-eastern Poland (the area acc. to Cieśliński 2003) and north-western Belarus. NE Poland consists of two administrative areas, Podlaskie and Warmińsko-Mazurskie voivodeships. NW Belarus consists of one administrative centre, Grodno.

Species of Rhizocarpon grow on erratics and stones in the area investigated. Those are postglacial boulders brought to the area by the Scandinavian ice-sheet in the Pleistocene. They occur individually or in larger clusters, forming boulder concentrations. Granite rocks constitute approximately $80 \%$ of erratic boulders in NE Poland and NW Belarus, the remaining ones being gneiss rocks. The greatest boulder concentrations in NE Poland can be found in the Suwalski Landscape Park with the greatest concentration of boulders in the lowlands in the „Głazowisko Bachanowo" reserve comprising ca ten thousand boulders (Kukwa, Fałtynowicz 2002). Fortifications dating from World War I in NW Belarus in the vicinity of Grodno are currently being investigated not only by historians but also by biologists.

\section{MATERIAL AND METHODS}

The material was collected during visits to respective habitats in north-eastern Poland (2002-2009) and north-western Belarus (1983-2008). Additionally, collections of Rhizocarpon deposited in the herbarium of the Institute of Biology, University 
of Białystok and GRSU, MSK-L herbaria were verified. Data concerning species of Rhizocarpon and their distribution in NE Poland was supplemented with literature data.

Species were verified and named according to Thomson (1997), Fryday (2002) and Ihlen (2004). Based on descriptions and recent taxonomic innovations as well as chemical, microscopic and morphological characters, an original key to all Rhizocarpon species found in the study area was prepared and is presented here. Chemical analyses were performed using thin-layer chromatography (TLC) according to Orange et al. (2001) with the use of solvents A and C.

\section{LIST OF SPECIES}

Rhizocarpon distinctum Th. Fr., Lichenogr. Scand. 1: 625 (1874).

Syn. Rhizocarpon ambiguum (Naeg.) A. Zahlbr.; Rh. hyalescens Vain.

For the description of the species see Ihlen (2004). Spot test reactions: thallus $\mathrm{K}+$ yellow, $\mathrm{C}-$, $\mathrm{KC}-$, PD-; medulla I+ blue, PD-, K-, C-. Substances detected by TLC: stictic acid in thallus and apothecia. The species was found on acid rocks. The habitats recorded were usually open and sunny.

$R$. distinctum is bipolar. It is known from North Europe, North America, South America and Antarctica. In Europe it has been reported from Belarus (Gorbach 1973), Germany (Wirth 1995), the Czech Republic (Vězda, Liška 1999), Lithuania (Motiejūnaitè 1999), Estonia (Randlane, Saag 1999), Austria (Hafellner, Türk 2001), Portugal (Boom, Jansen 2002), Spain (Llimona, Hladun 2001), Great Britain (Coppins 2002), Poland (Fałtynowicz 2003), Fennoscandia (Santesson et al. 2004; Ihlen 2004), Iceland (Kristinsson, Heidmarsson 2006).

The species is known from numerous localities in north-eastern Poland (Zielińska 1980; Cieśliński, Tobolewski 1989; Fałtynowicz 1994; Bystrek, Kolanko 2000; Cieśliński 2003; Zalewska et al. 2004a, b; Kolanko 2005; Kubiak 2005); however, it was reported from Central Belarus (Minsk region) only by Gorbach (1973) and Golubkov (1987).

SPecimens eXAmined. NE Poland. Wysoczyzna Białostocka high plain, Białystok, cemetery, stone gravestone, Oct. 2009, leg. A. Matwiejuk. NW BELARUS. Grodno region: Schutchinskiy district - ca 1 $\mathrm{km}$ SW of Orlya village, on the Niemen river, granite, 6 Sept. 1989, leg. V. Golubkov (MSK-L), vicinity of Pugachi village, geological monument of nature "Great Stone", 17 Aug. 1999, leg. V. Golubkov (MSK-L), vicinity of Jakubovichi village, granite, 16 June 1989, leg. V. Golubkov (MSK-L), vicinity of Kostenevo village, granite, 10 July 1999, leg. V. Golubkov (MSK-L); Zelvenskiy district - vicinity of Savichy village (1 km SW), stones, 15 Aug. 1999, leg. V. Golubkov (MSK-L); Svislotchskiy district - ca 1 km SW of Khlupin village, on Ros river, granite, 11 June 1983, leg. V. Golubkov (MSK-L); Mostovskiy district - ca $0.5 \mathrm{~km}$ SW of Lunno village, granite, 27 Apr. 1994, leg. V. Golubkov (MSK-L); Grodno district - ca $1 \mathrm{~km} \mathrm{SW}$ of Kamenka village, the sixth fort of the Grodno fortress, granite, 29 Sept. 2007, leg. V. Golubkov \& E. Bludov (GRSU), vicinity of Grodno, the second fort of the Grodno fortress, granite, 11 Aug. 1990, leg. V. Golubkov (GRSU), right riverside of the Niemen, granite, 7 Sept. 2004, leg. V. Golubkov (GRSU), 1 km NW of Podłabienie village, the third fort of the Grodno fortress, on moss-covered siliceous stones, 29 July 2008, leg. V. Golubkov (GRSU), $1.5 \mathrm{~km} \mathrm{NW}$ of Prigodichy village, on granite, 7 Sept. 2004, leg. V. Golubkov (GRSU).

Note. It is the first record of the species for North-Western Belarus. 
Rhizocarpon eupetraeum (Nyl.) Arnold, Flora 53: 478 (1870).

For the description of the species see Thomson (1997). Spot test reactions: thallus $\mathrm{K}+$ yellow-turning red, $\mathrm{C}-, \mathrm{KC}+$ red, $\mathrm{PD}+$ orange; medulla $\mathrm{K}+$ yellow turning red, PD+ yellow, C-, I+ deep blue. Substances detected by TLC: norstictic acid (Thomson 1997). The species was found on acid rocks.

The species is arctic and boreal. It is known from Northern Europe and North America. In Europe it has been reported from Germany (Wirth 1995), the Czech Republic (Vězda, Liška 1999), Lithuania (Motiejūnaite 1999), Austria (Hafellner, Türk 2001), Spain (Llimona, Hladun 2001), Poland (Fałtynowicz 2003), Fennoscandia (Santesson et al. 2004).

R. eupetraeum is known from three localities in North-Eastern Poland (Cieśliński 2003).

Rhizocarpon geographicum (L.) DC., Lamarck \& De Candolle, Fl. Franç., Edn 3 (Paris) 2: 365 (1805).

For the description of the species see Poelt (1988). Spot test reactions: medulla I+ blue, K-, C-, PD-; UV+ bright orange. Substances detected by TLC: rhizocarpic acid, psoromic acid in thallus and apothecia. The species was observed on acidic rocks, on boulders.

The species is cosmopolitan in colder areas. In Europe it has been reported from Belarus (Gorbach 1973), Germany (Wirth 1995), the Czech Republic (Vězda, Liška 1999), Lithuania (Motiejūnaite 1999), Estonia (Randlane, Saag 1999), Austria (Hafellner, Türk 2001), Portugal (Boom, Jansen 2002), Spain (Llimona, Hladun 2001), Great Britain (Coppins 2002), Poland (Fałtynowicz 2003), Fennoscandia (Santesson et al. 2004), Iceland (Kristinsson, Heidmarsson 2006), Albania (Hafellner 2007).

R. geographicum is known from numerous localities in North-Eastern Poland (see Zielińska 1980; Ciesliński, Tobolewski 1989; Fałtynowicz 1994; Kukwa, Fałtynowicz 2002; Cieśliński 2003; Zalewska et al. 2004a, b; Kolanko 2005; Kubiak 2005; Matwiejuk 2008). It was reported from Western Belarus by Gilibert (1781) and from Central Belarus (Minsk region) by Gorbach (1973).

Specimens examined. NE Poland. Dolina Biebrzy valley, granite, Oct. 2009, leg. A. Matwiejuk. NW BELARUS. Grodno region, Grodno district - right riverside of the Niemen, $1.5 \mathrm{~km} \mathrm{~W}$ of Prigodichi village, granite, 7 Sept. 2004, leg. V. Golubkov (GRSU), ca $1 \mathrm{~km} \mathrm{SW}$ of Kamenka village, the sixth fort of the Grodno fortress, granite, 29 Sept. 2007, leg. V. Golubkov, O. Ostrovska, D. Sviridov \& A. Levchuk (GRSU).

Rhizocarpon grande (Flörke) Arnold, Flora 54: 149 (1871).

Syn. Rhizocarpon endamyleum Th. Fr.

For the description of the species see Thomson (1997). Spot test reactions: medulla I+ blue, C+ red, PD-, K-. Substances detected by TLC: gyrophoric acid, stictic acid and norstictic acid in thallus and apothecia. The species was found on acidic rocks.

$R$. grande is bipolar. It is known from Mongolia (Golubkova 1983), North America (Thomson 1997), Antarctica (Øvstedal, Lewis Smith 2001). In Europe it has been reported from Germany (Wirth 1995), the Czech Republic (Vězda, Liška 1999), Austria (Hafellner, Türk 2001), Poland (Fałtynowicz 2003), Fennoscandia (Santesson et al. 2004) and Iceland (Kristinsson, Heidmarsson 2006). 
$R$. grande is known from one locality in north-eastern Poland (Zielińska 1980). It was reported from Central Belarus (Minsk region) by Gorbach (1973).

Specimens eXamined. NW Belarus. Grodno region: Schutchinskiy district - vicinity of Pugachi village, the "Great Stone" geological nature monument, 17 Aug. 1999, leg. V. Golubkov (MSK-L); Svislotchskiy district $-1 \mathrm{~km} \mathrm{SW}$ of Porozovo village, on the Ros River, granite, 11 June1983, leg. V. Golubkov (MSK-L).

Note. It is the first record of the species from North-Western Belarus.

Rhizocarpon hochstetteri (Körb.) Vain., Acta Soc. Fauna Fl. Fenn. 53: 280 (1922).

Syn. Catillaria hochstetteri Körber, Parerga Lichenol. 195 (1861); Rhizocarpon applanatum (Fr.) Th. Fr.; Rh. massalongii sensu Malme; Rh. crenulatum H. Magn.

For the description of the species see Fryday (2002). Spot test reactions: thallus $\mathrm{K}-, \mathrm{C}-$, PD-; medulla $\mathrm{K}-, \mathrm{C}-$, PD-, I-. Substances detected by TLC: lichen products not detected. The species was found on acidic rocks.

$R$. hochstetteri is circumpolar arctic. It is known from Europe, New Zealand (Fryday 2000b), Japan (Kurokawa 2003) and North America (Thomson 1997). In Europe it has been reported from Germany (Wirth 1995), Austria (Hafellner, Türk 2001), the British Isles (Fryday 2002), Poland (Fałtynowicz 2003), Fennoscandia (Santesson et al. 2004).

Specimen eXAmined. NW Belarus. Grodno region: Smorgonskiy district $-1.5 \mathrm{~km}$ SW of Balaban village, granite, 16 June 1989, leg. V. Golubkov (MSK-L).

Note. It is the first record of the species from Belarus.

Rhizocarpon lavatum (Fr.) Hazsl., Magyar. Birod. Zuzmó-Flór.: 206 (1884).

Syn. Rhizocarpon obscuratum f. lavatum (Fr.) Th. Fr.; Rh. orphninum (Vain.) Vain.

For the description of the species see Ihlen (2004). Spot test reactions: thallus K-; medulla I-. Substances detected by TLC: lichen products not detected. The species was found on acidic rocks.

The species is known from Germany (Wirth 1995), the Czech Republic (Vězda, Liška 1999), Austria (Hafellner, Türk 2001), Spain (Llimona, Hladun 2001), Portugal (Boom, Jansen 2002), Great Britain (Coppins 2002), Poland (Fałtynowicz 2003), Fennoscandia (Santesson et al. 2004) and Iceland (Kristinsson, Heidmarsson 2006).

Specimens eXAmined. NW Belarus. Grodno region: Smorgonskiy district $-1.5 \mathrm{~km} \mathrm{~W}$ of Balaban village, granite, 16 June 1999, leg. V. Golubkov (MSK-L); Grodno district - vicinity of Kamenka village, granite, 27 June 1997, V. Golubkov (MSK-L).

Note. This is the first records of the species from Belarus.

Rhizocarpon lecanorinum Anders, Hedwigia 64: 261 (1923).

For the description of the species see Poelt (1988). Spot test reactions: medulla $\mathrm{PD}+$ red, I+ blue, $\mathrm{K}+$ yellow; epithecium $\mathrm{K}-$; exciple $\mathrm{K}+$ red. Substances detected by TLC: psoromic acid in thallus and apothecia. The species grows on siliceous rocks, on boulders.

The species is known from Germany (Wirth 1995), the Czech Republic (Vĕzda, Liška 1999), Lithuania (Motiejūnaitè 1999), Estonia (Randlane, Saag 1999), Austria (Hafellner, Türk 2001), Spain (Llimona, Hladun 2001), Portugal (Boom, Jansen 2002), Great Britain (Coppins 2002), Poland (Fałtynowicz 2003), Fennoscandia (Santesson et al. 2004). 
R. lecanorinum is known from one locality in north-eastern Poland (Cieśliński, Tobolewski 1989; see also Kukwa and Fałtynowicz 2002; Cieślińki 2003; Zalewska et al. 2004b).

Rhizocarpon petraeum (Wulfen) A. Massal., Ric. Lich. Crost.: 102 (1852).

Syn. Rhizocarpon concentricum auct.; Rh. excentricum (Ach.) Arnold, Verh. Zool.-bot. Ges. Wien 29: 356 (1879); Siegertia petraea (Wulfen) V. Wirth.

For the description of the species see Ihlen (2004). Spot test reactions: thallus $\mathrm{K}+$ yellow; medulla I-, K-, C-, PD-. Substances detected by TLC: stictic acid in thallus and apothecia. The species was found on acidic rocks.

$R$. petraeum is circumpolar arctic and boreal. In Europe the species is known from Germany (Wirth 1995), the Czech Republic (Vězda, Liška 1999), Lithuania (Motiejūnaitè 1999), Austria (Hafellner, Türk 2001), Spain (Llimona, Hladun 2001), Great Britain (Coppins 2002), Iceland (Kristinsson, Heidmarsson 2006), Poland (Fałtynowicz 2003), Fennoscandia (Santesson et al. 2004). R. petraeum was reported from Central Belarus (Minsk region) by Gorbach (1973).

Specimens EXAmined. NW Belarus. Grodno region: Grodno district - ca $1 \mathrm{~km}$ SW of Kamenka village, the sixth fort of Grodno fortress, on moss-covered siliceous stones, 29 Sept. 2007, leg. V. Golubkov, O. Ostrovska, D. Sviridov \& A. Levchuk (MSK-L); Schutchinskiy district - vicinity of Jakubowice village, granite, 16 June 1989, leg. V. Golubkov (MSK-L).

Note. This is the first record of the species from North-Western Belarus.

Rhizocarpon polycarpum (Hepp) Th. Fr., Lichenogr. Scand. 1: 617 (1874).

Syn. Rhizocarpon confervoides sensu Rabenh., Kremp.; Rh. cyanescens (Hellb.) Zahlbr.

For the description of the species see Thomson (1997). Spot test reactions: thallus $\mathrm{K}+$ yellow, C-; medula I+ blue, K-, C-, PD-. Substances detected by TLC: stictic acid in thallus and apothecia. This species was found on acidic rocks, on boulders.

The species is bipolar. It is known from North Europe, North America (Thomson 1997), Australia (Fryday 2000b), Antarctica (Øvstedal, Lewis Smith 2001). In Europe it has been reported from Germany (Wirth 1995), the Czech Republic (Vězda, Liška 1999), Estonia (Randlane, Saag 1999), Austria (Hafellner, Türk 2001), Portugal (Boom, Jansen 2002), Spain (Llimona, Hladun 2001), Iceland (Kristinsson, Heidmarsson 2006), Great Britain (Coppins 2002), Poland (Fałtynowicz 2003) and Fennoscandia (Santesson et al. 2004).

It is known from several localities in north-eastern Poland (Bystrek and Kolanko 2000; Kukwa and Fałtynowicz 2002; Cieśliński 2003; Zalewska et al. 2004b; Kubiak 2005).-

Specimen examined. NW Belarus. Grodno region: Svislotchskiy district - Porozovo (1 km SW), on the Ros River, granite, 11 June 1983, leg. V. Golubkov (MSK-L).

Note. It is the first record of the species from Belarus.

Rhizocarpon reductum Th. Fr., Lichenogr. Scand. 1: 633 (1874).

Syn. Rhizocarpon obscuratum auct. not. (Ach.) A. Massal.

For the description of the species see Fryday (2000b). Spot test reactions: thallus $\mathrm{K}+$ yellow, $\mathrm{C}-$; medulla $\mathrm{I}-, \mathrm{C}-, \mathrm{K}+\mathrm{red}, \mathrm{PD}+$ orange. Substances detected by TLC: stictic acid in thallus and apothecia. The species was found on acidic rocks, on boulders.

The species is circumpolar. In Europe it has been reported from Germany (Wirth 1995), Poland (Fałtynowicz 2003) and Fennoscandia (Santesson et al. 2004; Ihlen 2004). 
It is known from several localities in North-Eastern Poland (Cieśliński, Tobolewski 1989, as R. obscuratum; Kukwa, Fałtynowicz 2002; Sparrius 2003; Zalewska et al. 2004b; Matwiejuk 2007). It was reported from Central Belarus (Minsk region) by Gorbach (1973).

Specimens examined. NE Poland. Wysoczyzna Białostocka high plain, Białystok city, cemetery, stone gravestone, Aug. 2005, leg. A. Matwiejuk. NW BELARUS. Grodno region: Novogrudokskiy district, $1 \mathrm{~km} \mathrm{SW}$ of Zhdanovitchy village, on the Roc River, granite, 6 June 1989, leg. V. Golubkov (MSK-L).

Note. It is the first record of the species from North-Western Belarus.

\section{KEY TO THE SPECIES OF RHIZOCARPON OCCURRING IN NORTH-EASTERN POLAND AND NORTH-WESTERN BELARUS}

1. Thallus yellow; containing rhizocarpic acid (UV+ bright orange) 2

1.* Thallus brown or ashy; lacking rhizocarpic acid (UV-) 3

2. Epithecium reddish, $\mathrm{K}+$ purple-violet R. geographicum

2.* Epithecium brownish, $\mathrm{K}-$; areoles mostly-shaped, each segment partly to entirely surrounding an apothecium R. lecanorinum

3. Ascospores 1- septate .. .4

3.* Ascospores muriform

4. Medulla $\mathrm{I}+$ blue, $\mathrm{K}-, \mathrm{C}-$; epithecium brown, $\mathrm{K}+$ violet-red R. polycarpum

4.* Medulla I-, $\mathrm{K}-, \mathrm{C}-$; epithecium green-brown, $\mathrm{K}-$ R. hochstetteri

5. Ascospores hyaline or only slightly darkened with age 6

5.* Ascospores very soon dark

6. Medulla I+ blue; epithecium red-brown, $\mathrm{K}+$ purple R. distinctum

6.* Medulla I... 7

7. Thallus pruinous; ascospores muriform, with $10-20$ cells R. petraeum

7.* Thallus epruinous . .8

8. Stictic acid present, thallus $\mathrm{K}+$ yellow R. reductum 8. * Substances not detected by TLC, thallus KR. lavatum

9. Medulla $\mathrm{K}-$ R. grande

9.* Medulla $\mathrm{K}+$ red R. eupatreum

\section{DISCUSSION}

The lichen biota in East-Central Europe has been studied reasonably well. Some groups of species, however, particularly Rhizocarpon species, are still poorly known in many regions (e.g., Belarus). As a result, many species frequent or even common in other areas of Europe have not been reported from a number of countries in central-east part of the continent. Twenty nine species of the genus have been reported in Poland so far (Faltynowicz 2003); six species were recorded in NE 
Poland (Cieśliński 2003) and six species in Belarus (Gorbach 1973). Of the eight taxa presented here, seven species of Rhizocarpon are reported for the first time for north-western Belarus, including three for Belarus. The occurrence of three species reported from NE Poland in literature data was confirmed in this study, with new localities recorded for them.

Rhizocarpon distinctum is the only common species in the study area while others are rare or very rare and were found at single localities.

Rocks and boulders, occurring singly or in small groups, are mostly suitable for their development in the lowland. In NE Poland, the area of the Suwalski Landscape Park covers lowland regions with a particularly large accumulation of mostly granite and gneiss boulders (Kukwa, Fałtynowicz 2002; Zalewska et al. 2004b). Boulders, stones and pebbles are in different habitat types: in the fields, balks, pastures, roads, on the slopes, in forests and their edges. Among the Rhizocarpon species characterized in the paper, R. geographicum and R. lecanorinum are rare in the lowlands. In NW Belarus, rare species of Rhizocarpon were recorded on the fortifications from World War I in Grodno.

Acknowledgements. We wish to thank the reviewers for their valuable remarks and advice.

\section{REFERENCES}

Boom, van den P. P. G., Jansen J. 2002. Lichens in the upper belt of the Serra da Estrela (Portugal). Österr. Zeitschr. Pilzk. 11: 1-28.

Bystrek J., Kolanko K. 2000. Porosty (Lichenes) Puszczy Knyszyńskiej. Zakład Poligraficzny BiS, Lublin, $98 \mathrm{pp}$.

Cieśliński S. 2003. Atlas rozmieszczenia porostów (Lichenes) w Polsce Północno-Wschodniej. Phytocoenosis 15 (N.S.), Suppl. Cartogr. Geobot.15, 430 pp.

Cieśliński S., Tobolewski Z. 1989. Porosty Polski północno-wschodniej. I. Acta Mycol. 25 (1): 57-100.

Coppins B. J. 2002. Checklist of lichens of Great Britain and Ireland. British Lichen Society, Huddersfield.

Fałtynowicz W. (ed.). 1994. Porosty Wigierskiego Parku Narodowego. Parki nar. Rez. Przyr. 13 (3): 9-28.

Fałtynowicz W. 2003. The lichens lichenicolous and allied fungi of Poland. An annotated checklist. W. Szafer Institute of Botany, Polish Academy of Sciences, Kraków, 435 pp.

Fryday A. M. 2000a. On Rhizocarpon obscuratum (Ach.) Massal., with notes on some related species in the British Isles. Lichenologist 32: 207-224.

Fryday A. M. 2000b. Additional lichen records from New Zealand 31. Australasian Lichenology 46: 336339.

Fryday A. M. 2002. A revision of the species of the Rhizocarpon hochstetteri group occurring in the British Isles. Lichenologist 34: 451-477.

Gilibert J. E. 1781. Flora lithuanica inchoata, seu Enumeratio plantarum Quas Circa Grodnam coll'egit et determinavit Joannes Emmanuel Gilibert. J. Gilibert. - Grodnae: Typis S.R.M. Primae collectionis. S. 98, 118-119.

Golubkov V. V. 1987. Species composition and structure of lichenoflora of the state national park Belovezhskaya Pushcha, 85 pages. - manuscript (deposited at VINITI 22.04.87, deposition No. 2829B87).

Golubkova N. S. 1983. An Analysis of the Lichen Flora of Mongolia. Nauka, Leningrad, 248 pp.

Gorbach N. V. 1973. Lishajniki Belorussii. Nauka i Technika, Minsk, 1-583.

Hafellner J. 2007. Checklist and bibliography of lichenized and lichenicolous fungi so far reported from Albania (version 05-2007). Fritschiana 59: 1-18.

Hafellner J., Türk R. 2001. Die lichenisierten Pilze Österreichs-eine Checkliste der bisher nachgewiesenen Arten mit Verbreitungsangaben. Stapfia 76: 1-167.

Holtan-Hartwig J., Timdal E. 1987. Notes on some parasitic Rhizocarpon species. Lichenologist 19: 335338. 
Ihlen P. G. 2004. Taxonomy of the non-yellow species of Rhizocarpon (Rhizocarpaceae, lichenized Ascomycota) in the Nordic countries, with hyaline and muriform ascospores. Mycological Research 108: 533-570.

Kolanko K. 2005. Porosty Biebrzańskiego Parku Narodowego i terenów przylegających. (In:) A. Dyrcz, C. Werpachowski (eds). Przyroda Biebrzańskiego Parku Narodowego. Monografia. Biebrzański Park Narodowy. Osowiec Twierdza, 149-160.

Kristinsson H., Heidmarsson S. 2006. Checklist of lichens in Iceland. Internet version. http://www.floraislands.is/fletlist.htm

Kubiak D. 2005. Lichens and lichenicolous fungi of Olsztyn town (NE) Poland. Acta Mycol. 40 (2): 293 332.

Kukwa M., Fałtynowicz W. 2002. Porosty rezerwatu „Głazowisko Bachanowo nad Czarną Hańczą” i przyległego lasu łęgowego w Suwalskim Parku Krajobrazowym. Parki nar. Rez. Przyr. 21 (4): 375-84.

Kurokawa S. (ed.) 2003. Checklist of Japanese Lichens. National Science Museum, Tokyo, 128 pp.

Llimona X., Hladun N. L. 2001. Checklist of the lichens and lichenicolous fungi of the Iberian Peninsula and Balearic Islands. Bocconea 14: 1-581.

Matwiejuk A. 2008. Nowe stanowisko Rhizocarpon geographicum (Rhizocarpaceae) w Polsce północnowschodniej. Fragm. Florist. Geobot. 15 (2): 25-27.

Motiejūnaitė J. 1999. Checklist of lichens and allied fungi of Lithuania. Botanica Lithuanica 5 (3): 251269.

Orange A., James P. W., White, F. J. 2001. Microchemical methods for the identification of lichens. British Lichen Society, London, $101 \mathrm{pp}$.

Øvstedal D. O., Lewis Smith, R. I. 2001. Lichens of Antarctica and South Georgia. A guide to their identification and ecology. Cambridge, Cambridge University Press, 411 pp.

Poelt J. 1990. Parasitische Arten der Flechtengattung Rhizocarpon: eine weiter Übersicht. Mitteilungen der Botanischen Staatssamlung München 29: 515-538.

Poelt J., Hafellner J. 1982. Rhizocarpon vorax spec. nov. (Lichenes) und seine Beutegenossen auf Pertusaria. Herzogia 6: 309-321.

Poelt J., Vězda A. 1984. Rhizocarpon inimicum spec. nov. eine weitere parasitische Flechte auf Lecanora rupicola spec. coll. Herzogia 6: 469-475.

Randlane T., Saag A. 1999. Second checklist of lichenized, lichenicolous and allied fungi of Estonia. Folia Cryptog. Estonica 34: 1-132.

Runemark H. 1956a. Studies in Rhizocarpon I. Taxonomy of the yellow species in Europe. Opera Botanica 2 (1): 1-152.

Runemark H. 1956b. Studies in Rhizocarpon II. Distribution and ecology of the yellow species in Europe. Opera Botanica 2 (2): 1-150.

Santesson R., Moberg R., Nordin A., Tønsberg T., Vitikainen O. 2004. Lichen-forming and lichenicolous fungi of Fennoscandia. Uppsala, Museum of Evolution, Uppsala University, 359 pp.

Sparrius L. B. 2003. Contribution to the lichen floras of the Białowieża Forest and the Biebrza Valley (Eastern Poland). Herzogia 16: 155-160.

Thomson J. W. 1967. Notes on Rhizocarpon in the Arctic. Nova Hedwigia 14: 421-481.

Thomson J. W. 1997. American Arctic lichens 2. The microlichens. Madison, University of Wisconsin Press, $675 \mathrm{pp}$.

Vězda A., Liška J. 1999. Katalog Lišejníků České Republiky. Institute of Botany, Academy of Sciences of the Czech Republic, Průhonice.

Wirth V. 1995. Die Flechten Baden-Württembergs. Bd.1-2, II Aufl. Stuttgart, Verl. Eugen Ulmer.

Zalewska A., Fałtynowicz W., Krzysztofiak A., Krzysztofiak L., Picińska-Fałtynowicz, J. 2004a. Lichens of Romincka Primeval Forest. (In:) A. Zalewska, W. Fałtynowicz (eds). Lichens of the protected areas in the Eurogion Niemen. "Man and Nature" Association, Suwałki, 51-110.

Zalewska A., Fałtynowicz W., Krzysztofiak A., Krzysztofiak L., Picińska-Fałtynowicz J. 2004b. Lichens of Suwalski Landscape Park. (In:) A. Zalewska, W. Fałtynowicz (eds). Lichens of the protected areas in the Eurogion Niemen. "Man and Nature" Association, Suwałki, 5-50.

Zielińska J. 1980. Porosty głazów narzutowych Wysoczyzn Podlaskich. Acta Mycol. 5: 135-148. 
Nowe notowania gatunków Rhizocarpon

z Polski Północno-Wschodniej i Północno-Zachodniej Białorusi

\section{Streszczenie}

Celem niniejszej pracy jest uzupełnienie danych o porostach z rodzaju Rhizocarpon na terenie Polski Północno-Wschodniej i Północno-Zachodniej Białorusi. Na terenie NE Polski odnotowano trzy nowe stanowiska Rhizocarpon $-R$. distinctum, $R$. geographicum i $R$. reductum, a na terenie NW Białorusi osiem gatunków $-R$. distinctum, $R$. geographicum, $R$. grande, $R$. hochstetteri, $R$. lavatum, $R$. petraeum, $R$. polycarpum, $R$. reductum. Siedem gatunków ( $R$. distinctum, $R$. grande, $R$. hochstetteri, $R$. lavatum, $R$. petraeum, $R$. polycarpum, $R$. reductum) jest podanych po raz pierwszy dla zachodniej Białorusi, a trzy gatunki ( $R$. hochstetteri, $R$. lavatum, $R$. polycarpum) są nowe dla Białorusi. Opracowano autorski klucz do gatunków występujących na badanym obszarze. 